\title{
Electron Microprobe Analysis of Complex Y-REE-Ta-Nb-Ti Minerals from the Petaca Pegmatite District, New Mexico
}

\author{
Michael N. Spilde ${ }^{1}$, William P. Moats ${ }^{2}$, Steve Dubyk ${ }^{3}$ and Brain Salem ${ }^{4}$ \\ 1. Institute of Meteoritics, University of New Mexico, Albuquerque, New Mexico, 87131, USA \\ 2. 8409 Fairmont Drive NW, Albuquerque, New Mexico, 87120, USA \\ 3. 1828 Quiet Lane SW, Albuquerque, New Mexico, 87105, USA \\ 4. PO Box 27, Tijeras, New Mexico, 87059, USA
}

High-tech electronic applications, such as high-energy density batteries and super strong magnets, have brought about renewed interest in locating strategic deposits of rare earth element (REE) minerals. All types of REE deposits are being investigated around the world. Granitic pegmatites represent an uncommon source of REE minerals, in addition to providing other industrial minerals such as feldspar or beryl. The Petaca Pegmatite District, in north-central New Mexico, contains at least 88 individual rareelement pegmatite bodies in an area about $7 \mathrm{~km}$ wide by $24 \mathrm{~km}$ long, as described by Jahns [1]. Many of the pegmatite bodies were mined for sheet and scrap mica from about 1870 through the end of World War II, with some mining continuing into the late 1950's and perhaps as late as 1965.

REE-bearing Nb-Ta oxides are among the more interesting minerals that occur in the Petaca district. However, the identities of many of the minerals are sometimes tentative, and for many years, published information simply classified all black, metamict minerals as "samarskite." Due to the uncertainty of which particular REE-bearing $\mathrm{Nb}$-Ta oxides actually occur in the Petaca District, we are in the process of conducting a district-wide survey of the Petaca REE minerals. To date, Y-REE-Nb-Ta-Ti oxides and other minerals have been sampled from 30 individual pegmatites for analysis by electron microprobe. Based on the results of our microprobe study, several new minerals were identified or confirmed for the district, including euxenite-(Y), samarskite-(Y), polycrase-(Y), xenotime-(Y), betafite, microlite, pyrochlore, and uranmicrolite. See Table 1 for formulas.

The Y-REE-Ta-Nb-Ti oxide minerals examined in this study are highly complex. Figure 1 shows examples of the complexity of the minerals, including primary inclusions (Fig. 1A), exsolution (Fig. 1B), overgrowth (Fig. 1C), and alteration (Fig. 1D). Zoning within minerals, such as Ta exchanging for $\mathrm{Nb}$ across a columbite crystal, reflects changes in the composition of the pegmatite fluid during primary growth of the crystal. Furthermore, late enrichment of titanium and tantalum in the late stages of pegmatite crystallization resulted in Ta-rich minerals (struverite, and microlite) forming around the margins of pre-existing minerals (Fig. 1C), extending from the existing $\mathrm{AB}_{2} \mathrm{O}_{6}$ structure. Secondary alteration by late pegmatitic fluids further complicates the picture. Alteration by these late fluids is apparent in Fig. 1D where xenotime replaces samarskite along fractures, and infiltration of fluids rich in $\mathrm{U}, \mathrm{Ta}$, and $\mathrm{Ca}$ has formed microlite that overprints all the other phases.

Differentiating between Y-REE-Ta-Nb-Ti oxide minerals is hampered not only by the complex chemistry of the minerals, but also by the fact that they are often metamict and display weak or no X-ray diffraction patterns. Ewing [2] used a statistical approach to classify the Y-REE-Ta-Nb-Ti oxides, and Ercit [3] further refined the technique using principle component analysis (PCA). We take the same approach, using a three-group statistical model. The PCA plot in Figure 1E indicates that most of the differentiation is found in light (LREE) vs. heavy REE (HREE) associated with primary crystallization. 
For example polycrase has higher levels of HREE but euxenite has lower levels of HREE, while samarskite exhibits higher levels of LREE. $\mathrm{Ta}, \mathrm{Ca}$, and $\mathrm{Pb}$, which are associated with microlite and pyrochlore resulting from late stage alteration, are strongly anti-correlated with all other elements.

Table 1. Y-REE-Ta-Nb-Ti Minerals identified at the Petaca pegmatites.

\begin{tabular}{ll}
\multicolumn{1}{c}{ Mineral Name } & \multicolumn{1}{c}{ Ideal Formula } \\
\hline Aeschynite-(Y) & $(\mathrm{Y}, \mathrm{Ca}, \mathrm{Fe})(\mathrm{Ti}, \mathrm{Nb})_{2}(\mathrm{O}, \mathrm{OH})_{6}$ \\
Betafite & $(\mathrm{Ca}, \mathrm{U})_{2}(\mathrm{Ti}, \mathrm{Nb}, \mathrm{Ta})_{2} \mathrm{O}_{6}(\mathrm{OH})$ \\
Columbite-(Mn) & $(\mathrm{Mn}, \mathrm{Fe})\left(\mathrm{Nb}, \mathrm{Ta}_{2}\right)_{6}$ \\
Euxenite-(Y) & $(\mathrm{Y}, \mathrm{Ca}, \mathrm{Ce})\left(\mathrm{Nb}, \mathrm{Ta}_{6}, \mathrm{Ti}\right)_{2} \mathrm{O}_{6}$ \\
Microlite & $(\mathrm{Na}, \mathrm{Ca})_{2} \mathrm{Ta}_{2} \mathrm{O}_{6}(\mathrm{O}, \mathrm{OH}, \mathrm{F})$ \\
Monazite-(Ce) & $(\mathrm{Ce}, \mathrm{La}, \mathrm{Nd}, \mathrm{Th}) \mathrm{PO}_{4}$ \\
Polycrase-(Y) & $(\mathrm{Y}, \mathrm{Ca}, \mathrm{Ce}, \mathrm{U}, \mathrm{Th})(\mathrm{Ti}, \mathrm{Nb}, \mathrm{Ta})_{2} \mathrm{O}_{6}$ \\
Pyrochlore & $(\mathrm{Na}, \mathrm{Ca})_{2} \mathrm{Nb}_{2} \mathrm{O}_{6}(\mathrm{OH}, \mathrm{F})$ \\
Samarskite-(Y) & $\left(\mathrm{Y}, \mathrm{Fe}{ }^{3+}, \mathrm{U}\right)\left(\mathrm{Nb}, \mathrm{Ta}_{5} \mathrm{O} \mathrm{O}_{4}\right.$ \\
Uranmicrolite & $(\mathrm{U}, \mathrm{Ca})_{2}(\mathrm{Ta}, \mathrm{Nb})_{2} \mathrm{O}_{6}(\mathrm{OH}, \mathrm{F})$ \\
Xenotime-(Y) & $(\mathrm{Y}, \mathrm{REE}) \mathrm{PO}_{4}$
\end{tabular}

References:

[1] Jahns, R. H., New Mexico Bureau Mines and Mineral Resources Bulletin 25 (1946), 294 p.

[2] Ewing, R.C., Canadian Mineralogist 14 (1976), p. 111.

[3] Ercit, T. S., Canadian Mineralogist 43 (2005), p. 1291
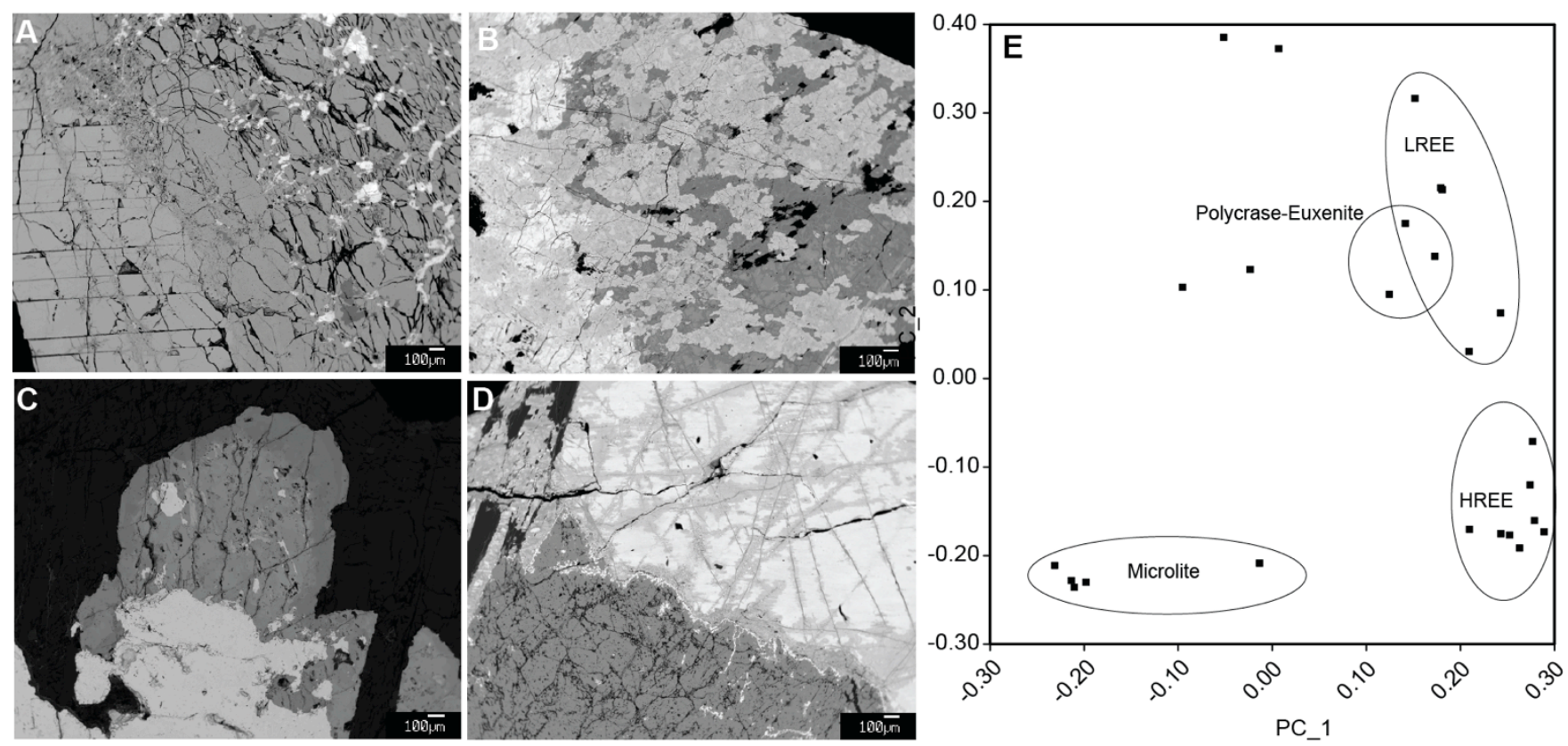

Figure 1. Backscattered electron (BSE) micrographs of Petaca minerals. Scale bars are $100 \mu \mathrm{m}$. (A) Thorite inclusions (white) in monazite (medium gray). Compare cleavages in the crystalline monazite at the left with the shattered appearance in the metamict, inclusion-rich region on the right. (B) Exsolution of polycrase (light) from samarskite (medium gray) and alteration by pyrochlore (gray). (C) Overgrowth of Ta-bearing rutile (struverite) on columbite (light). (D) Dark gray zircon associated with samarskite (light), altered by xenotime along fractures (medium gray) with microlite veinlets (white). (E) Plot of the scores of canonical variables 1 and 2 for the Y-REE-Ta-Nb-Ti minerals. 